\title{
Effects of age on intestinal phosphate transport and biochemical values of broiler chickens
}

\author{
Jianhui $\mathrm{Li}^{1,2, a}$, Jianmin Yuan ${ }^{2, a}$, Zhiqiang Miao', and Yuming Guo ${ }^{2, *}$
}

* Corresponding Author: Yuming Guo Tel: +86-1062733900, Fax: +86-1062733900,

E-mail: guoyum@cau.edu.cn

'College of Animal Science and Veterinary Medicine, Shanxi Agricultural University, Shanxi 030801, China

${ }^{2}$ State Key Laboratory of Animal Nutrition, College of Animal Science and Technology, China Agricultural

University, Beijing 100193, China

a These authors contributed equally to this work. Submitted Jul 18, 2016; Revised Sept 5, 2016; Accepted Sept 21, 2016
Objective: The objective of this experiment was to characterize the mRNA expression profile of type IIb sodium-inorganic phosphate cotransporter (NaPi-IIb) and the biochemical values of serum alkaline phosphatase (AKP), calcium, inorganic phosphorus, tibial ash and minerals of broiler chickens with aging.

Methods: A total of 56 one-day-old Arbor Acres male broiler chickens were used. Broiler chickens were weighed and samples were collected weekly from day 1 .

Results: The result showed that before the growth inflection point, ash, calcium, and phosphorus content in the tibia of broiler chickens increased with growth (before 3 weeks of age), although there were no significant differences in chicks at different ages in the later period of the experiment and weight gain rate was relatively slow at this stage (4 to 6 weeks). $\mathrm{NaPi}-\mathrm{IIb}$ gene expression in the small intestine in the early growth stage was higher than that in the later growth stage. Expression of calbindin and the vitamin D receptor protein in the intestinal mucosa increased with age in the duodenum and jejunum. Serum AKP activity first increased and subsequently decreased after peaking at 1 week of age, but there was no significant difference after 3 weeks of age.

Conclusion: These results show that compared with the early growth stage, the weight-gain rate of broiler chickens in the late growth stage gradually decreased with gradual tibia maturation, along with weaker positive transport of phosphorus in the intestine and reinforced re-absorption of phosphorus in the kidney, which might be the reason that phosphorus requirement in the late growth stage was decreased.

Keywords: Broiler Chickens, Growth, Intestinal Transport, Phosphorus, Biochemical Values

\section{INTRODUCTION}

Selective pressure increases the growth rate of broiler chickens, but leg weakness also inadvertently evolves, which could bring economic loss and animal welfare concern. Intestinal absorption, renal excretion, and re-absorption of phosphate are essential for whole body phosphorus homeostasis, especially for bone development. Among the bone development indexes, bone density was found to be related to calcium and phosphorus transport in the small intestine, as high bone density is regulated by increased calcium transport and decreased phosphorus transport in the small intestine [1]. A significantly positive correlation exists between tibia ash and bone density [2].

Type IIb sodium-coupled phosphate transporter (NaPi-IIb) is a critical transport protein for phosphorus absorption in the small intestine [3]. The absorption of phosphorus in the small intestine can rapidly alter the content of phosphorus in serum with the kidneys rapidly responding to regulate phosphate excretion. NaPi-IIb expression in the intestine could be regulated by the active form of vitamin $\mathrm{D}_{3}\left[1,25(\mathrm{OH})_{2} \mathrm{D}_{3}\right]$, and dietary phosphorus [4-5]. The level of circulating phosphate is related to age and diet for mammals, which is con- 
trolled by several hormones, including parathyroid hormone (PTH), 1,25(OH $)_{2} \mathrm{D}_{3}$, and fibroblast growth factor 23 [6]. Previous studies have shown that the demand for phosphorus is reduced with the growth of broiler chickens, regardless of the feeding standard [7-8]. Rat studies have also indicated that the absorption and secretion of calcium and phosphorus are affected by age and growth development [9]. In vivo studies in rats showed that absorption of sodium-dependent inorganic phosphate by the small intestinal brush border membrane is decreased with increased age and the effects of $1,25(\mathrm{OH})_{2} \mathrm{D}_{3}$ on intestinal $\mathrm{NaPi}$-IIb transport is greater in young rats than adult rats $[1,10]$. However, a limited number of studies investigated the effects of age on the metabolism and requirement of calcium and phosphorus in rapidly growing broilers. Bar et al [11] found that restriction of dietary calcium and phosphorus could highly influence tibia ash content of chickens aged 21 days, but this influence was relatively low in those aged 43 days. Our previous studies also showed that diets with high nutrient density significantly decreased tibia ash content of broiler chickens at 0 to 3 weeks of age, but had no significant influence at 4 to 6 weeks $[12,13]$. However, few studies have been conducted to demonstrate the age effect on the discrepancy of calcium and phosphorus absorption and metabolism in broilers.

Hence, the aims of this study were to demonstrate the decreased expression of NaPi-IIb transport mRNA with aging, and the changes in values of the biochemical parameters of serum alkaline phosphatase (AKP), calcium, inorganic phosphorus, tibial ash and minerals (calcium and phosphorus). Results of the experiment could explain the reasons for the change in phosphorus requirement between the early and late phases of broiler growth, as described in our previous studies $[12,13]$.

\section{MATERIALS AND METHODS}

\section{Animals and diets}

The study protocol was approved by the ethics committee and performed in accordance with the Guidelines for Experimental Animal Welfare of China Agricultural University (Beijing, China). A total of 56 one-day-old Arbor Acres Plus broiler chickens (Beijing Arbor Acres Poultry Breeding Company, Beijing, China) were selected and randomly allotted into eight pens, with seven chickens in each pen. The experimental period was 42 days.

The broiler chickens were fed the same diet with consistent metabolic energy, crude protein, calcium, and non-phytate phosphorus, on the basis of the values recommended by the Chinese Chicken Feeding Standard Requirements (NY/T 332004). An ideal amino acid content was prepared based on the proportions of lysine, methionine, threonine, and tryptophan of 100:45:73:18. The diet was prepared according to the measured values of non-phytate phosphorus, calcium, and crude protein in feedstuffs. The dietary composition and nutrients are shown in Table 1.
Chicks were raised in battery cages and each pen was equipped with a feeder and water supply. All birds were allowed to consume mash feed and tap water ad libitum. The temperature was maintained at $34^{\circ} \mathrm{C}$ from 1 to 3 days of age and then gradually reduced to room temperature. The photoperiod was set at 24 $\mathrm{h}$ of light. The relative humidity was maintained at $60 \%$ to $65 \%$ throughout the experimental period.

\section{Measurements}

Broiler chickens at $0,1,2,3,4,5$, and 6 weeks of age were weighed individually. After weighing, blood samples were taken from eight broiler chickens at each week. The blood samples were drawn from the wing vein and centrifuged at 3,600 $\times \mathrm{g}$ for 10 min. Serum was stored at $-30^{\circ} \mathrm{C}$ until assayed. All birds which were bled were killed through cervical dislocation and the duodenal (from distal of the gizzard to $1 \mathrm{~cm}$ distal of the bile duct) and jejunal (the middle of the jejunum) segments were isolated immediately and the digesta was thoroughly washed out with cold $1 \%$ diethylpyrocarbonate-treated water and the mucosa was scraped off on ice using a glass microscope slide and quickly frozen in liquid nitrogen for later determination of RNA and protein expression profiles. The left tibias from individual birds were excised, sealed in plastic bags, and stored at $-30^{\circ} \mathrm{C}$ for further

Table 1. Composition of diets and nutrient levels for broilers

\begin{tabular}{|c|c|c|}
\hline Dietary ingredients (\%) & 0 to 3 weeks & 4 to 6 weeks \\
\hline Corn & 54.53 & 58.78 \\
\hline Soybean meal & 37.04 & 33.06 \\
\hline Soybean oil & 3.82 & 4.30 \\
\hline Salt & 0.30 & 0.30 \\
\hline Trace mineral premix ${ }^{1)}$ & 0.20 & 0.20 \\
\hline Vitamin premix & 0.03 & 0.03 \\
\hline DL-methionine & 0.20 & 0.10 \\
\hline Choline chloride & 0.30 & 0.30 \\
\hline Aureomycin & 0.10 & 0.10 \\
\hline Antioxidant & 0.03 & 0.03 \\
\hline Dicalcium phosphate & 1.77 & 1.18 \\
\hline Limestone & 1.68 & 1.62 \\
\hline Total & 100 & 100 \\
\hline \multicolumn{3}{|l|}{ Nutrient composition) } \\
\hline Metabolizable energy (kcal/kg) & 2,950 & 3,050 \\
\hline Crude protein & 21.02 & 19.50 \\
\hline Calcium & 1.10 & 0.90 \\
\hline Nonphytate phosphorus & 0.50 & 0.40 \\
\hline Lysine & 1.13 & 1.02 \\
\hline Methionine & 0.51 & 0.40 \\
\hline Tryptophan & 0.27 & 0.25 \\
\hline Threonine & 0.88 & 0.81 \\
\hline
\end{tabular}

1) Nutrients per kilogram of diet: $\mathrm{Cu}$ (from $\mathrm{CuSO}_{4} \cdot 5 \mathrm{H}_{2} \mathrm{O}$ ), $16 \mathrm{mg}$; Fe (from $\mathrm{FeSO}_{4} \cdot 7 \mathrm{H}_{2} \mathrm{O}$ ), $80 \mathrm{mg} ; \mathrm{Zn}$ (from $\mathrm{ZnSO}_{4} \cdot 7 \mathrm{H}_{2} \mathrm{O}$ ), $110 \mathrm{mg} ; \mathrm{Mn}$ (from $\mathrm{MnSO}_{4} \cdot \mathrm{H}_{2} \mathrm{O}$ ), $120 \mathrm{mg}$; I from $\left.\mathrm{Ca}\left(\mathrm{IO}_{3}\right)_{2} \cdot \mathrm{H}_{2} \mathrm{O}\right), 1.5 \mathrm{mg} ; \mathrm{Co}$ (from $\left.\mathrm{CoCl}_{2} \cdot 6 \mathrm{H}_{2} \mathrm{O}\right), 0.5 \mathrm{mg}$; Se (from organic selenium), 0.3 $\mathrm{mg}$.

${ }^{2)}$ Nutrients per kilogram of diet: vitamin $A, 12,500 \mathrm{IU}$; vitamin $\mathrm{D}_{3}, 3,000 \mathrm{IU}$; vitamin $\mathrm{E}_{\text {, }}$ $25 \mathrm{mg}$; vitamin $\mathrm{K}_{3}, 2.5 \mathrm{mg}$; thiamin, $2.5 \mathrm{mg}$; riboflavin, $8 \mathrm{mg}$; vitamin $\mathrm{B}_{12}, 0.025 \mathrm{mg}$; folic acid, $1.25 \mathrm{mg}$; niacin, $37.5 \mathrm{mg}$; pantothenic acid, $12.5 \mathrm{mg}$; biotin, $0.125 \mathrm{mg}$.

${ }^{3)}$ Calculated values. 
analysis.

Tibial ash, $\mathrm{Ca}$, and $\mathrm{P}$ concentrations: The left tibia was defleshed by hand and the patella was removed, weighed, air dried for $24 \mathrm{~h}$ at room temperature, and then defatted to determine bone ash content and concentrations of $\mathrm{Ca}$ and P. Dry-defatted tibias were ashed in a muffle furnace at $550^{\circ} \mathrm{C}$ for $16 \mathrm{~h}$ and tibia ash was measured on the basis of the percentage of dry weight. Calcium and phosphorus concentrations were determined by ethylenediaminetetraacetic acid titration and the ammonium metavanadate colorimetric method, respectively, and both are presented on the basis of dry-defatted weight [14].

Analysis of serum calcium, phosphorus, and alkaline phosphatase: Serum inorganic phosphorus, calcium levels, and AKP activity were measured using commercial kits (Nanjing Jiancheng Bioengineering Institute, Nanjing, China).

Total RNA extraction, reverse transcription, and real-time polymerase chain reaction: Total RNA was extracted from the duodenal and jejunal mucosa of broiler chickens at each week using the SV Total RNA Isolation System (Z3100; Promega Corporation, Madison, WI, USA) in accordance with the manufacturer's instructions. The resulting extracts were re-suspended in diethylpyrocarbonate-treated water. The concentration and quality of RNA were determined by measuring absorbance at $260 \mathrm{~nm}$ and agarose gel electrophoresis, respectively [12]. Afterward, $1.0 \mu \mathrm{g}$ of total RNA was reverse-transcribed into singlestranded cDNA with AMV reverse transcriptase and an Oligo (dT) 15 primer in the presence of recombinant RNasin ribonuclease inhibitor (A3500; Promega Corporation, USA). The mRNA of NaPi-IIb was subjected to real-time polymerase chain reaction (PCR) with $\beta$-actin as an internal control standard. The primers used in this experiment and the lengths of the obtained PCR products are shown in Table 2. Real-time PCR was conducted using an ABI 7500 fluorescent quantitative PCR system with N RealSuper Mixture (with ROX) (CW0767, Beijing ComWin Biotech Co., Ltd., Beijing, China). The following realtime PCR protocol was applied: $95^{\circ} \mathrm{C}$ for $4 \mathrm{~min}$ and 40 cycles at $95^{\circ} \mathrm{C}$ for $15 \mathrm{~s}, 60^{\circ} \mathrm{C}$ for $60 \mathrm{~s}$, and $60^{\circ} \mathrm{C}$ to $95^{\circ} \mathrm{C}$. Melting curve analysis was then performed. Each gene was amplified in triplicate. Standard curves were also created to determine amplification efficiency. Relative standard curve methods were used to quantify gene expression. The results are expressed as the ratio of target gene mRNA to $\beta$-actin mRNA [15].

Western blot analysis for calbindin and vitamin $D$ receptor protein: The duodenal and jejunal brush border membrane vesicles were homogenized and centrifuged at $10,000 \times \mathrm{g}$ for 5 $\min$ at $4^{\circ} \mathrm{C}$. The resulting supernatants were stored at $-80^{\circ} \mathrm{C}$ until further use. Protein concentration was determined with the Bradford assay [16]. Samples of the brush border membrane vesicles were boiled in Laemmli buffer (Sigma-Aldrich, St. Louis, MO, USA) for $5 \mathrm{~min}$ to denature proteins. Then, $50 \mu \mathrm{g}$ of brush border membrane vesicle protein was loaded onto each lane and separated on a $4 \%$ polyacrylamide gel prior to protein transfer to a polyvinylidene difluoride membrane for $2 \mathrm{~h}$. The polyvinylidene difluoride membrane was then probed for the presence of the vitamin D receptor (VDR) or Calbindin by incubation for at least $1 \mathrm{~h}$ with primary antibodies diluted to 1:1,000 (VDR: ab8756; Calbindin: ab25085; Abcam, Cambridge, MA, USA). After washing with Tris-buffered saline Tween-20, the polyvinylidene difluoride membrane was incubated with secondary antibodies conjugated with horseradish peroxidase (dilution, 1:5,000; Bio-Rad Laboratories, Hercules, CA, USA). Immunoblots were visualized on X-ray film by chemiluminescence (Pierce Protein Research Products, Rockford, IL, USA) and image analysis was performed on optical density-calibrated images using AlphaEase Stand Alone Software (Alpha Innotech, Santa Clara, CA, USA) as described by Li et al [17].

\section{Statistical analysis}

All analyses were performed using SPSS ver. 16.0 software (IBMSPSS, Inc., Chicago, IL, USA). Data are presented as mean values. One-way analysis of variance was used to determine the significance of the main effects and interaction. All data were subjected to normal distribution and variance consistency testing. Differences between all processed data meeting variance consistency were tested using the Duncan multiple comparison test and the data that did not satisfy variance consistency were tested using the Dunnett's $C$ multiple test. Differences were considered significant at $\mathrm{p}<0.05$. Growth curves of broiler chickens were described with the Gompertz nonlinear regression model. The Gompertz equation was calculated using the SPSS NLIN model [18]. The growth curve was of the following form:

$$
\mathrm{W}_{\mathrm{t}}=\mathrm{a} \exp [-\exp (\mathrm{b}-\mathrm{c} \times \mathrm{t})]
$$

in which $\mathrm{W}_{\mathrm{t}}$ is the weight $\mathrm{f}$ bird at age $(\mathrm{t})$ with three parameters $(a, b$, and $c)$, where $b / c=$ age in days at the inflection point and $\mathrm{a} / \mathrm{e}=$ weight at the inflection point. To study the effect of age on tibia ash, calcium, and phosphorus contents, the results were fitted to a quadratic equation [11]. The coefficients of determination $\left(R^{2}\right)$ served as measures of goodness of fit.

Table 2. Oligonucleotide polymerase chain reaction primers

\begin{tabular}{lllll}
\hline Gene & GenBank accession & Orientation & Primer sequence (5' to 3') & Predicted size (bp) \\
\hline NaPi-Ilb & NM_204474.1 & Forward & CTTTTACTTGGCTGGCTGGAT & 148 \\
\multirow{3}{*}{-Actin } & Reverse & AGGGTGAGGGGATAGGACG & 100 \\
& NM_205518.1 & Forward & AACACCCACACCCCTGTGAT & \\
\hline
\end{tabular}




\section{RESULTS}

\section{Growth model}

The weights of AA broiler chickens significantly increased with age $(\mathrm{p}<0.01)$, while the rate of weight gain at the inflection point of the growth curve reached the maximum value at 26 days. The Gompertz nonlinear regression curve was listed in Figure 1.

\section{Tibial parameters}

As shown in Table 3, tibia ash, calcium, and phosphorus contents were significantly affected by age $(\mathrm{p}<0.01)$. The tibia ash and calcium contents were increased significantly with age until 3 weeks, after which no difference was observed. Tibia phosphorus content was also significantly increased with age until 2 weeks, with no significant difference thereafter. Trend analysis showed that tibia ash, calcium $(\mathrm{Ca})$ and phosphorus $(\mathrm{P})$ contents assumed a quadratic curve response with increasing age. The fitting curve equations are as follows:

$$
\begin{aligned}
& Y_{\text {ash }}=-0.632 \mathrm{x}^{2}+6.856 \mathrm{x}+34.87\left(\mathrm{R}^{2}=0.991\right) \\
& Y_{P}=-0.119 \mathrm{x}^{2}+1.268 \mathrm{x}+5.961\left(\mathrm{R}^{2}=0.940\right) \\
& Y_{\mathrm{Ca}}=-0.253 \mathrm{x}^{2}+2.707 \mathrm{x}+12.24\left(\mathrm{R}^{2}=0.984\right)
\end{aligned}
$$

in which $\mathrm{Y}_{\text {ash }}, \mathrm{Y}_{\mathrm{P}}$ and $\mathrm{Y}_{\mathrm{Ca}}$ are the contents of tibia ash, calcium, and phosphorus, respectively, and $\mathrm{x}$ is the age in weeks. The $\mathrm{x}$ values (week) for maximal ash, P, Ca is $5.42,5.33,5.35$, respectively.

The relative tibia weight significantly increased with age until 3 weeks $(\mathrm{p}<0.01)$ (Table 3 ), while no significant difference was observed in the following growth period. The fitting curve equation was quadratic as follows:

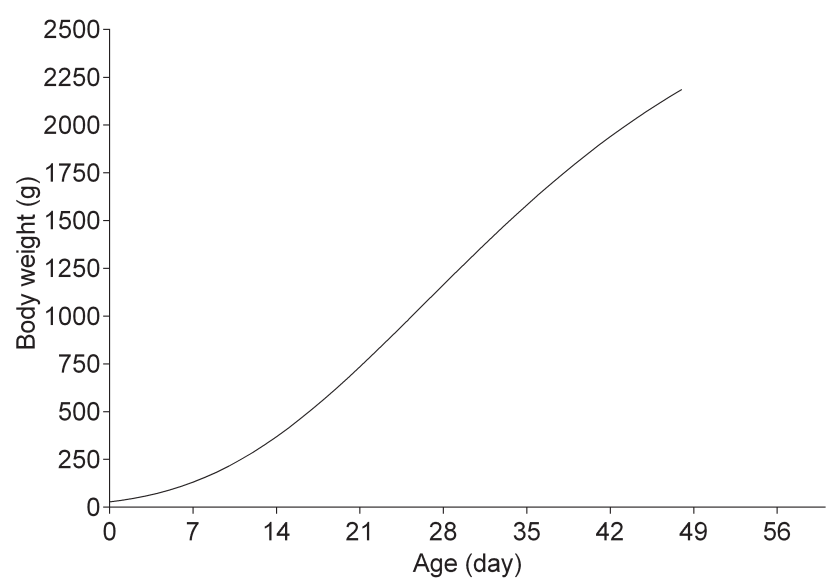

Figure 1. The growth curve based on Gompertz nonlinear regression model of broiler chickens. The model equation is $W_{t}=2,914 \times \exp (-\exp [1.538-0.058 \times t])$, in which Wt is the weight of bird at age (t).
Table 3. Tibial parameters of broiler tibias as influenced by ages

\begin{tabular}{lcccc}
\hline $\begin{array}{c}\text { Age } \\
\text { (weeks) }\end{array}$ & Ash (\%) & Phosphorus (\%) & Calcium (\%) & $\begin{array}{c}\text { Relative tibia } \\
\text { weight (\%) }\end{array}$ \\
\hline 0 & $40.73^{\mathrm{a}}$ & $6.91^{\mathrm{a}}$ & $14.77^{\mathrm{a}}$ & $0.72^{\mathrm{a}}$ \\
1 & $46.49^{\mathrm{b}}$ & $8.20^{\mathrm{b}}$ & $16.53^{\mathrm{b}}$ & $0.88^{\mathrm{ab}}$ \\
2 & $49.84^{\mathrm{c}}$ & $8.95^{\mathrm{c}}$ & $17.92^{\mathrm{c}}$ & $1.01^{\mathrm{b}}$ \\
3 & $52.45^{\mathrm{d}}$ & $9.07^{\mathrm{c}}$ & $19.36^{\mathrm{d}}$ & $1.26^{\mathrm{c}}$ \\
4 & $53.06^{\mathrm{d}}$ & $9.06^{\mathrm{c}}$ & $19.47^{\mathrm{d}}$ & $1.19^{\mathrm{c}}$ \\
5 & $52.59^{\mathrm{d}}$ & $9.14^{\mathrm{c}}$ & $19.02^{\mathrm{d}}$ & $1.18^{\mathrm{c}}$ \\
6 & $52.34^{\mathrm{d}}$ & $9.14^{\mathrm{c}}$ & $18.88^{\mathrm{d}}$ & $1.18^{\mathrm{c}}$ \\
SEM & 0.602 & 0.111 & 0.245 & 0.041 \\
p-value & $<0.001$ & $<0.001$ & $<0.001$ & 0.001 \\
\hline
\end{tabular}

SEM, standard error of the mean.

1) Relative tibia weight was compared with body weight.

${ }^{a-d}$ Within a column, values not sharing a common superscript letter are significantly different $(p<0.05)$.

$$
\mathrm{Y}_{\text {bone/BW }}=-0.025 \mathrm{x}^{2}+0.281 \mathrm{x}+0.445\left(\mathrm{R}^{2}=0.936\right)
$$

in which $\mathrm{Y}_{\text {bone/BW }}$ is the relative tibia weight compared with body weight and $\mathrm{x}$ is the age in weeks. The $\mathrm{x}$-values (week) for maximal tibia weight is 5.62 .

\section{Serum $\mathrm{Ca}$ and $\mathrm{P}$ concentrations and alkaline phosphatase activity}

As shown in Table 4, there were significant differences in AKP activities and $\mathrm{Ca}$ content in the serum of broiler chickens with different ages $(\mathrm{p}<0.01)$. Serum AKP activity was lowest at hatch and increased to the highest level after 1 week of age and then gradually decreased until 4 weeks of age with constant AKP activity afterward. Serum Ca content was highest at the age of 2 weeks. No significant differences in serum P content were observed between broiler chickens at different ages (in weeks).

\section{Phosphorus and calcium transporter expression in the small intestine}

As shown in Table 5, the expression of NaPi-IIb mRNA in the intestinal mucosa was significantly affected by age and intestinal section of broiler chickens. The expression of NaPi-IIb mRNA

Table 4. Physiological changes in serum of broiler chickens with age

\begin{tabular}{lccc}
\hline $\begin{array}{c}\text { Age } \\
\text { (weeks) }\end{array}$ & $\begin{array}{c}\text { AKP } \\
(\mathrm{U} / \mathbf{1 0 0} \mathbf{~ m L})\end{array}$ & $\begin{array}{c}\text { Serum Ca } \\
(\mathbf{m m o l} / \mathrm{L})\end{array}$ & $\begin{array}{c}\text { Serum P } \\
(\mathbf{m m o l} / \mathrm{L})\end{array}$ \\
\hline 0 & $96^{\mathrm{a}}$ & $1.75^{\mathrm{a}}$ & 1.40 \\
1 & $785^{\mathrm{c}}$ & $1.86^{\mathrm{a}}$ & 1.45 \\
2 & $750^{\mathrm{c}}$ & $2.20^{\mathrm{b}}$ & 1.55 \\
3 & $412^{\mathrm{b}}$ & $1.86^{\mathrm{a}}$ & 1.57 \\
4 & $214^{\mathrm{a}}$ & $1.81^{\mathrm{a}}$ & 1.37 \\
5 & $153^{\mathrm{a}}$ & $1.92^{\mathrm{a}}$ & 1.57 \\
6 & $159^{\mathrm{a}}$ & $1.71^{\mathrm{a}}$ & 1.7 \\
SEM & 49.9 & 0.04 & 0.06 \\
p-value & $<0.001$ & 0.021 & 0.821
\end{tabular}

AKP, alkaline phosphatase; SEM, standard error of the mean.

${ }^{a-c}$ Within a column, values not sharing a common superscript letter are significantly different $(p<0.05)$. 
Table 5. Cotransporter expression in the duodenal and jejunal mucosa of broiler chickens affected by ages

\begin{tabular}{|c|c|c|c|c|c|c|}
\hline \multirow{2}{*}{ Age (weeks) } & \multicolumn{2}{|c|}{ NaPi-2b mRNA expression } & \multicolumn{2}{|c|}{ Calbindin protein abundance } & \multicolumn{2}{|c|}{ VDR protein abundance } \\
\hline & Duodenum & Jejunum & Duodenum & Jejunum & Duodenum & Jejunum \\
\hline 0 & $0.92^{c}$ & $1.00^{\mathrm{bc}}$ & $0.42^{\mathrm{a}}$ & $0.43^{\mathrm{a}}$ & $0.26^{\mathrm{a}}$ & $0.36^{\mathrm{a}}$ \\
\hline 1 & $0.75^{\mathrm{bc}}$ & $1.09^{b c}$ & $0.54^{\mathrm{ab}}$ & $0.68^{b}$ & $0.38^{b}$ & $0.44^{\mathrm{ab}}$ \\
\hline 2 & $0.82^{\mathrm{bc}}$ & $1.04^{b c}$ & $0.66^{\mathrm{abc}}$ & $0.76^{b}$ & $0.44^{b}$ & $0.54^{b c}$ \\
\hline 3 & $1.45^{d}$ & $1.43^{b c}$ & $0.82^{\mathrm{bcd}}$ & $1.00^{c}$ & $0.61^{\mathrm{cd}}$ & $0.60^{\text {cd }}$ \\
\hline 4 & $0.90^{b c}$ & $1.79^{c}$ & $0.95^{\mathrm{cd}}$ & $1.20^{\mathrm{d}}$ & $0.57^{c}$ & $0.75^{\mathrm{de}}$ \\
\hline 5 & $0.29^{\mathrm{a}}$ & $0.49^{\mathrm{a}}$ & $1.17^{\mathrm{d}}$ & $1.33^{\mathrm{d}}$ & $0.74^{d}$ & $0.81^{\mathrm{e}}$ \\
\hline 6 & $0.67^{\mathrm{bc}}$ & $0.83^{\mathrm{ab}}$ & $1.09^{d}$ & $1.19^{d}$ & $0.69^{\text {cd }}$ & $0.63^{\mathrm{cd}}$ \\
\hline SEM & 0.054 & 0.06 & 0.062 & 0.061 & 0.034 & 0.032 \\
\hline \multicolumn{7}{|l|}{ Main effect } \\
\hline \multicolumn{7}{|l|}{ Weeks } \\
\hline 0 & \multicolumn{2}{|c|}{$0.958^{b}$} & \multicolumn{2}{|c|}{$0.422^{\mathrm{a}}$} & \multicolumn{2}{|c|}{$0.306^{a}$} \\
\hline 1 & \multicolumn{2}{|c|}{$0.918^{b}$} & \multicolumn{2}{|c|}{$0.611^{b}$} & \multicolumn{2}{|c|}{$0.413^{b}$} \\
\hline 2 & \multicolumn{2}{|c|}{$0.930^{b}$} & \multicolumn{2}{|c|}{$0.711^{b}$} & \multicolumn{2}{|c|}{$0.491^{b}$} \\
\hline 3 & \multicolumn{2}{|c|}{$1.437^{c}$} & \multicolumn{2}{|c|}{$0.909^{c}$} & \multicolumn{2}{|c|}{$0.606^{c}$} \\
\hline 4 & \multicolumn{2}{|c|}{$1.345^{c}$} & \multicolumn{2}{|c|}{$1.073^{\mathrm{cd}}$} & \multicolumn{2}{|c|}{$0.660^{c}$} \\
\hline 5 & \multicolumn{2}{|c|}{$0.388^{\mathrm{a}}$} & \multicolumn{2}{|c|}{$1.249^{d}$} & \multicolumn{2}{|c|}{$0.773^{d}$} \\
\hline 6 & \multicolumn{2}{|c|}{$0.749^{b}$} & \multicolumn{2}{|c|}{$1.141^{\mathrm{d}}$} & \multicolumn{2}{|c|}{$0.657^{c}$} \\
\hline \multicolumn{7}{|l|}{ Intestinal site } \\
\hline Duodenum & \multicolumn{2}{|c|}{0.826} & \multicolumn{2}{|c|}{0.807} & \multicolumn{2}{|c|}{0.527} \\
\hline Jejunum & \multicolumn{2}{|c|}{1.095} & \multicolumn{2}{|c|}{0.941} & & \\
\hline$p$-value & & & & & & \\
\hline Age & & & & & & \\
\hline Site & & & & & & \\
\hline Age $\times$ Site & & & & & & \\
\hline
\end{tabular}

NaPi-Ilb: Type Ilb sodium-coupled phosphate transporter; VDR: vitamin D receptor; SEM, standard error of the mean.

${ }^{a-d}$ Within a column, values with no common letter indicate significant differences $(p<0.05)$.

in the jejunum was significantly higher than that in duodenum $(\mathrm{p}<0.05)$. Expression of NaPi-IIb mRNA in the jejunum was highest at 4 weeks of age, while that in the duodenum was highest at 3 weeks. A conic curve change was also found for both the duodenum and jejunum. No interaction effect was observed between age (in weeks) and intestinal section ( $p>0.05$ ).

Calbindin protein abundance in the intestinal mucosa increased with age (in weeks) in the duodenum and jejunum till three weeks of age $(\mathrm{p}<0.01)$, but there was no significant difference in expression during the later growth period (4 to 6 weeks) (Figure 2). Expression of the calbindin protein in the small intestine generally showed a conic curve change, reaching a peak value at 5 weeks of age. Calbindin protein abundance in the jejunum was significantly higher than that in the duodenum $(p<0.01)$ and significant interaction effect was observed between age and intestinal section $(\mathrm{p}<0.01)$.

Expression of the VDR protein in the intestinal mucosa was significantly increased with age $(\mathrm{p}<0.01)$ (Figure 2$)$. A conic curve change was observed with the increase in age generally in the proximal section of the small intestine (including the duodenum and jejunum), reaching a peak value at 5 weeks of age. Expression of the VDR protein in the jejunum was significantly higher than that in the duodenum $(\mathrm{p}<0.05)$ and no interaction effect was observed between age (in weeks) and intestinal section $(\mathrm{p}>0.05)$.

(a) Duodenum

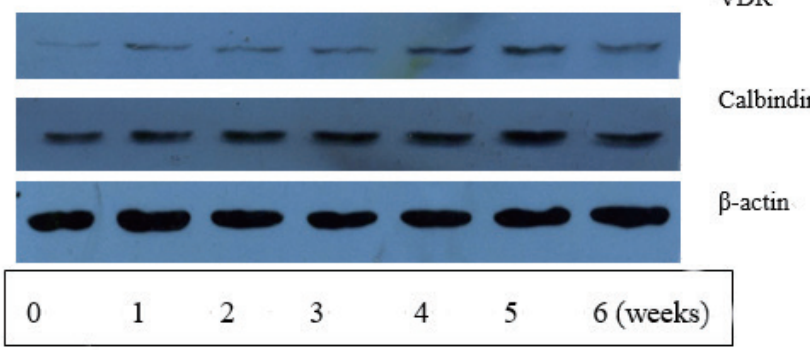

(b) Jejunum

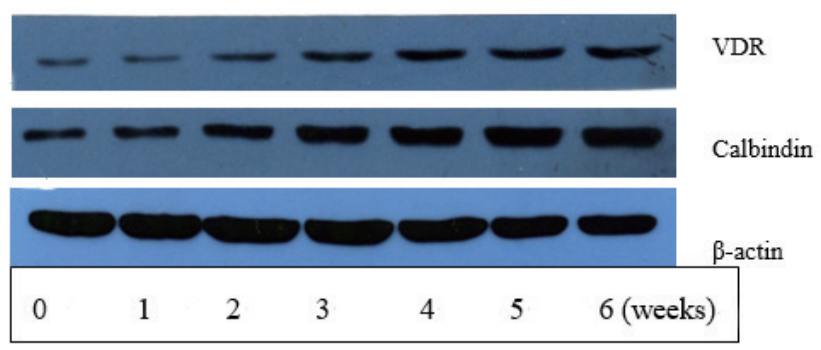

Figure 2. Pictures of the results for western blotting of vitamin D receptor (VDR) and calbindin protein. 


\section{DISCUSSION}

Growth patterns are used to summarize time series data into a few parameters to enable an objective comparison of growth efficiencies [18]. The growth inflection point is a very important parameter of a curve equation to describe the growth of broiler chickens. In the early growth stage, weight gain refers to the process of exponential increase, and weight-gain speed gradually becomes rapid. When the body weight is at a certain stage (inflection point), the weight-gain speed will reach a peak value and then gradually decreases and body weight reaches a maximum value with maturity [19]. The logistic, Gompertz, and Richards nonlinear models for fitting of growth curves are the most commonly used. Among these, the Gompertz model is the most universal in avian studies and has the highest curve fit $[19,20]$. In this study, the Gompertz model to fit the growth curve of AA broiler chickens showed an inflection point of 26 days. Studies have reported that differential growth of chicks before and after the inflection point could account for the variations in intestinal morphology associated with age with increased crypt depth for villus growth for chicks at middle ages [21].

Ash content, bone density, and relative tibia weight are regarded as the most sensitive indexes for measuring whole body phosphorus status. A significantly positive correlation was observed between ash and bone density in the tibia [2]. Lumbar bone mineral density was also found to be correlated with renal phosphate reabsorption [22]. The results of the present study showed that tibia ash, calcium, and phosphorus content, as well as the relative tibia weight, were significantly increased in the first 3 weeks of growth; however, these changes were unremarkable afterward. These results were in accordance with those of Barrerio et al [2], who also reported that bone density of broiler chickens significantly increased with age, and calcium, phosphorus, and magnesium concentrations in tibia ash were increased significantly till 22 days of age, but with no significant change between 22 and 43 days. In this study, the growth inflection point according to the fitted growth curve was 26 days. During the first 3 weeks, to satisfy the requirement of rapid growth rate, bone metabolism is also gradually enhanced. Bone density and bone strength are increased by deposition of a large amount of inorganic matter for support of higher body weight gain. At 4 to 6 weeks of age, weight-gain speed is gradually retarded and bone metabolism strength also becomes weak. Therefore, the bone will be in a mature stage to support stable growth. Moreover, Ozeraitiene and Butenaite [23] reported a significantly negative correlation between fat deposit in vivo and bone density. As is known, fat deposition is accelerated in the later growth stage of broiler chickens compared with that in the early periods, thus bone density will be at lower levels in later growth stages.

Phosphorus absorption in the intestine could be affected by the location of the intestine, but exhibited discrepancies. Our study concludes that the expression of calcium or phosphorus transporters in the jejunum was higher than that in the duodenum of broiler chickens, which was consistent with the results of Blahos et al [24], who indicated that the jejunum was the largest section of the small intestine for absorption of phosphorus. Fox et al [25] compared the absorption of ${ }^{32} \mathrm{P}$ in the ileum and duodenum of 4-week-old broilers, and concluded that absorption in the ileum was higher than that in the duodenum under any content combination of calcium and phosphorus. However, a study of 28-day broiler chickens by Yan and Angel et al [26] showed that NaPi-IIb mRNA expression in the duodenum was the highest, followed by the jejunum and ileum. Han et al [15] also pointed out that NaPi-IIb mRNA expression in the intestine of 11-day-old broiler chickens occurred as follows: duodenum $>$ jejunum $>$ ileum. Study also reported that the amount of NaPi-IIb transport proteins and the transport speed of intestinal brush border membrane vesicles in the ileum were the greatest in a mouse model [27]. Other studies had reported that the section of the small intestine with the highest absorption of $\mathrm{NaPi}$ differed according to age, which was retracted in the proximal small intestine with an increase in age [28]. Thus, we deduced that the primary location of phosphorus absorption in the intestine could not be determined only according to the results at a certain age.

Many human and rat studies have shown that phosphate absorption in the small intestine is negatively correlated with age $[1,10]$. Our results are basically consistent with those of $\mathrm{Xu}$ et al [10], who compared NaPi-IIb gene expression levels of 2-, 3-, and 6-week-old rats and adult rats, and concluded that expression decreased with age. Wang and Yin [29] also reported that $\mathrm{NaPi}$ transport activity and $\mathrm{NaPi}$-IIb carrier protein and mRNA expression in the small intestine of lactating pigs was higher than adult pigs. Zhao and Nemere [30] pointed out that with the growth of broilers, $1,25 \mathrm{D}_{3}$-MARRS (membrane activated rapid response to steroids) mRNA expression and PKC (protein kinase $\mathrm{C}$ ) activity were decreased. Thus, stimulation of phosphorus absorption by $1,25(\mathrm{OH})_{2} \mathrm{D}_{3}$ in the intestine is weakened with aging $[31,32]$. This result may be one of the reasons that expression of the NaPi-IIb carrier is decreased with age. Study showed that stimulation of phosphorus absorption by $1,25(\mathrm{OH})_{2} \mathrm{D}_{3}$ in the small intestine of adult rats (not for the young rats) may be regulated at the translational level, rather than the transcriptional level of $\mathrm{NaPi}-\mathrm{IIb}$, thus the regulation of $\mathrm{NaPi}$-IIb gene expression by $1,25(\mathrm{OH})_{2} \mathrm{D}_{3}$ is correlated with age [10]. The synthesis of active vitamin $\mathrm{D}_{3}$ can be promoted by PTH through stimulation of the gene promoter 25-OH- $\mathrm{D}_{3}$-1 $\alpha$-hydroxylase [33] and PTH promotes calcium re-absorption and suppresses phosphate reabsorption in the proximal tubules [6]. The lower calcium content in serum and $1,25(\mathrm{OH})_{2} \mathrm{D}_{3}$-VDR protein abundance in the intestine might be associated with the lower secretion of PTH, through which phosphorus re-absorption might be enhanced. Calbindin is an important transport protein of calcium, 
as its expression directly affects calcium absorption and metabolism, which in turn regulates bone development [34]. The active absorption of calcium in the intestine was also found to be correlated with age [35] and mediated by vitamin $\mathrm{D}$, regardless of gene or non-gene levels [36]. Activated vitamin $\mathrm{D}_{3}$ can be combined with its nucleic acid receptor $1,25(\mathrm{OH})_{2} \mathrm{D}_{3}$-VDR in the small intestine to stimulate the exchange transport of the TRPV $5 / 6$ pathway, calbindin, $\mathrm{Ca}^{2+}$-ATPase, and $\mathrm{Na}^{+} / \mathrm{Ca}^{2+}$, thereby promoting calcium absorption in the intestine [36]. Richard and James [37] reported that the regulation of $1,25(\mathrm{OH})_{2} \mathrm{D}_{3}$ on calcium absorption by the small intestine was decreased with increased age in rats. However, this research was based only on 7-week, 4-month, and 17-month-old rats. Rats reach sexual maturity at 2 months, which may cause a decrease in calcium absorption. However, broiler chickens enter a rapid growth stage before 6 weeks of age, meantime the intestine is still under development. Therefore, calcium absorption in the growth stage will increase with age. Bar et al [11] also pointed out that broiler chickens grow rapidly and maintain higher bone formation rates at 43 days of age, while the content of calciumbinding protein in the duodenum is still high. High bone density is related to high transport of calcium and low transport of phosphorus in the small intestine [38]. Hence, our experimental results are basically consistent with those of previous reports. These findings show that the two absorption pathways of calcium and phosphorus in intestine differ with age.

AKP is secreted from osteoblasts and decreased AKP activity is associated with bone ossification. Our study found that AKP activity was weakened with age, which was in agreement with the findings of Dobado-Berrios and Ferrer [39], who reported that AKP might be a useful parameter for age-predicting purposes. In the present study, changes in AKP activity were consistent with changes in ash, calcium, and phosphorus deposition in the tibia. We deduced that bone mobilization activities are decreased in the late growth period.

The balance of phosphorus in vivo is regulated by bone, the small intestine, and kidneys [40]. Thus, we concluded that compared with the early growth stage, the weight-gain rate of broiler chickens in the late growth stage is gradually decreased, and the tibia is gradually matured, along with weaker positive transport of phosphorus in the intestine and reinforced re-absorption of phosphorus in the kidneys, which might be the reason that phosphorus requirement in the late growth stage was decreased.

\section{CONFLICT OF INTEREST}

We certify that there is no conflict of interest with any financial organization regarding the material discussed in the manuscript.

\section{ACKNOWLEDGMENTS}

This study was financially supported by the ear-marked fund for
Modern Agro-Industry Technology Research System (CARS-42), the National Youth Science Fund Project of China (31301992), and the National Science and Technology Support Plan projects (2012BAD39B0402-03).

\section{REFERENCES}

1. Armbrecht HJ. Effect of age on calcium and phosphate absorption. Role of 1,25-dihydroxyvitamin D. Miner Electrol Metab 1990;16: 159-66.

2. Barreiro FR, Sagula AL, Junqueira OM, Pereira GT, Baraldi-Artoni SM. Densitometric and biochemical values of broiler tibias at different ages. Poult Sci 2009;88:2644-48.

3. Marks J, Debnam ES, Unwin RJ. Phosphate homeostasis and the renal-gastrointestinal axis. Am J Physiol-Renal 2010;299:F285-F96.

4. Hattenhauer O, Traebert M, Murer H, Biber J. Regulation of small intestinal Na-Pi type IIb cotransporter by dietary phosphate intake. Am J Physiol-Gastr L 1999;277:G756-G62.

5. Murer H, Forster I, Biber J. The sodium phosphate cotransporter family SLC34. Pflügers Arch 2004;447: 763-67.

6. Michigami T. Regulatory mechanism of circulating inorganic phosphate. Clin Calcium 2016;26:193-8.

7. Waldroup PW, Kersey JH, Saleh EA, et al. Nonphytate phosphorus requirement and phosphorus excretion of broiler chicks fed diets composed of normal or high available phosphate corn with and without microbial phytase. Poult Sci 2000;79:1451-59.

8. Dhandu AS, Angel R. Broiler nonphytin phosphorus requirement in the finisher and withdrawal phases of a commercial four-phase feeding system. Poult Sci 2003;82:1257-65.

9. Howe JC, Beecher GR. Dietary protein and phosphorus: effect on calcium and phosphorus metabolism in bone, blood and muscle of the rat. J Nutr 1983;113:2085-95.

10. Xu H, Bai L, Collins JF, Ghishan FK. Age-dependent regulation of rat intestinal type IIb sodium-phosphate cotransporter by 1,25 $(\mathrm{OH})_{2}$ vitamin $\mathrm{D}_{3}$. Am J Physiol Cell Physiol 2002;282:487-93.

11. Bar A, Shinder D, Yosefi S, Vax E, Plavnik I. Metabolism and requirements for calcium and phosphorus in the fast-growing chicken as affected by age. Br J Nutr 2003;89:51-60.

12. Li JH, Yuan JM, Guo YM, et al. The effect of dietary nutrient density on growth performance, physiological parameters and small intestinal type IIb sodium phosphate co-transporter expression in broilers. J Anim Sci Biotech 2011;2:102-10.

13. Li JH, Yuan JM, Miao ZQ, et al. Effect of dietary nutrient density on small intestinal phosphate transport and bone mineralization of broilers during the growing period. Plos one 2016;11:e0153859.

14. Wang JJ, Wang JR, Fu ZL, Lou P, Ren H. Effects of dietary calcium and phosphorus levels on bone growth in broilers from 1 to 3 weeks of age. Chinese J Anim Nutr 2010;22:1088-95.

15. Han JC, Yang XD, Zhang T, et al. Effects of 1alpha-hydroxycholecalciferol on growth performance, parameters of tibia and plasma, meat quality, and type IIb sodium phosphate cotransporter gene expression of one- to twenty-one-day-old broilers. Poult Sci 2009; 
$88: 323-9$

16. Bradford MM. Rapid and sensitive method for the quantitation of microgram quantities of protein utilizing the principle of proteindye binding. Anal Biochem 1976;72:248-54.

17. Li JH, Yuan JM, Guo YM, Sun QJ, Hu XF. The influence of dietary calcium and phosphorus imbalance on intestinal $\mathrm{NaPi}$-IIb and calbindin mRNA expression and tibia parameters of broilers. Asian-Australas. J Anim Sci 2012;25:552-8.

18. Nahashon SN, Aggrey SE, Adefope NA, Amenyenu A, Wright D. Growth characteristics of pearl gray guinea fowl as predicted by the richards, gompertz, and logistic models. Poult Sci 2006;85: 359-63.

19. Wu ZX. Comparative analysis of different growth model on the early growth stage of Ross 308 broilers. Gansu Sci and Technol 2010; 26:149-52.

20. Chen ZM. Dynamic growth model and correlative parameters of broilers. [Ph.D. Thesis] Beijing, China: Chinese Academy of Agricultural Sciences; 2004.

21. Mahmoud KZ, Edens FW. Breeder age affects small intestine development of broiler chicks with immediate or delayed access to feed. Br. Poult Sci 2012;53:32-41.

22. Takeuchi Y, Kuroda T, Sugimoto T, Shiraki M, Nakamura T. Renal phosphate reabsorption is correlated with the increase in lumbar bone mineral density in patients receiving once-weekly teriparatide. Calcif. Tissue Int 2016;98:186-92.

23. Ozeraitiene V, Butenaite V. The evaluation of bone mineral density based on nutritional status, age, and anthropometric parameters in elderly women. Medicina 2006;42:836-42.

24. Blahos J, Care AD. Alternate-day betamethasone treatment does not affect intestinal absorption of calcium and phosphate and growth rate of chicks. Endocrinol Exp 1981;15:199-204.

25. Fox J, Care AD. Stimulation of duodenal and ileal absorption of phosphate in the chick. Calcif Tissue Res 1978;26:243-5.

26. Yan F, Angel R, Ashwell CM. Characterization of the chicken small intestine type IIb sodium phosphate cotransporter. Poult Sci 2007; 86:67-76.

27. Radanovic T, Wagner CA, Murer H, Biber J. Regulation of intestinal phosphate transport I. Segmental expression and adaptation to low-Pi diet of the type IIb Na+-Pi cotransporter in mouse small intestine. Am J Physiol-Gastr L 2005;288:G496-G500.
28. Borowitz SM, Granrud GS. Ontogeny of intestinal phosphate absorption in rabbits. Am J Physiol 1992;262:G847-G53.

29. Wang B, Yin Y. Regulation of the type IIb sodium-dependent phosphate cotransporter expression in the intestine. Front Agr China 2009;3:226-30.

30. Zhao B, Nemere I. $1,25(\mathrm{OH})_{2} \mathrm{D}_{3}$-mediated phosphate uptake in isolated chick intestinal cells: Effect of $24,25(\mathrm{OH})_{2} \mathrm{D}_{3}$, signal transduction activators, and age. J Cell Biochem 2002;86:497-508.

31. Nemere I, Farach-Carson MC, Rohe B, et al. Ribozyme knockdown functionally links a $1,25(\mathrm{OH})_{2} \mathrm{D}_{3}$ membrane binding protein $\left(1,25 \mathrm{D}_{3}\right.$ MARRS) and phosphate uptake in intestinal cells. Proc Natl Acad Sci USA 2004;101:7392-7.

32. Tunsophon S, Nemere I. Protein kinase C isotypes in signal transduction for the $1,25 \mathrm{D}_{3}$-MARRS receptor (ERp57/PDIA3) in steroid hormone-stimulated phosphate uptake. Steroids 2010;75:307-13.

33. Brenza HL, Kimmel-Jehan C, Jehan F, et al. Parathyroid hormone activation of the 25-hydroxyvitamin $\mathrm{D}_{3}$-1a-hydroxylase gene promoter. Proc Natl Acad Sci USA 1998;95:1387-91.

34. Yu L, Wang YQ, Zhang SY, et al. Gene cloning, sequencing and eukaryotic expression plasmid construction of chicken calbindinD28k. Chin J Anim Vet Sci 2008;39:1329-35.

35. Tryfonidou MA, Van den Broek J, Van den Brom WE, Hazewinkel HA. Intestinal calcium absorption in growing dogs is influenced by calcium intake and age but not by growth rate. J Nutr 2002; 132:3363-8

36. Adriana VP, Gabriela PAR. Minireview on regulation of intestinal calcium absorption emphasis on molecular mechanisms of transcellular pathway. Int J Gastroenterol 2008;77:22-34.

37. Richard JW, James CFK. Intestinal calcium absorption in the aged rat: evidence of intestinal resistance to $1,25(\mathrm{OH})_{2}$ vitamin D. Endocrinology 1998;139:3843-8.

38. Armbrecht HJ, Boltz MA, Hodam TL. Differences in intestinal calcium and phosphate transport between low and high bone density mice. Gastr L 2002;282:G130-6.

39. Dobado-Berrios PM, Ferrer M. Age-related changes of plasma alkaline phosphatase and inorganic phosphorus, and late ossification of the cranial roof in the spanish imperial eagle (Aquila adalberti C. L. Brehm, 1861). Physiol Zool 1997;70:421-7.

40. Bergwitz C, Juppner H. Regulation of phosphate homeostasis by PTH, vitamin D, and FGF23. Annu Rev Med 2010;61:91-104. 